\title{
Projeto terapêutico singular - intervenções do núcleo de apoio à Saúde da Família (NASF) de Piranga-MG
}

\author{
Adriana Alves Reis, Brunéria Rezende, Irene Gonçalves, Naisy Milagres, Natália Alves, Roberta \\ Teixeira
}

\section{Resumo}

O núcleo de Apoio à Saúde da Família (NASF) implantado no município de Piranga-MG em 2009 visa oferecer apoio matricial à 07 equipes de Estratégia Saúde da Família (ESF). Seus profissionais vêm utilizando como principal estratégia de gestão da clínica a construção do Projeto Terapêutico Singular (PTS), caracterizado como um movimento de co-produção e co-gestão do cuidado individual e coletivo de casos que se evidenciam pela situação de vulnerabilidade-complexidade. Desta forma, assegura-se de modo dinâmico e interativo retaguarda especializada às equipes e profissionais de referência, buscando integralidade no cuidado, intersetorialidade da rede municipal, realizando o movimento com o usuário e sua família, colocando-os como parte mais interessada no caso. Os objetivos são ajudar o individuo-família a restabelecer relações afetivas e sociais, reconquistar direitos, buscar a autonomia afetiva-material-social e reincorporar-se na vida social e política, retirar os profissionais do isolamento e dar o suporte para que os mesmos lidem com a complexidade dos sujeitos e seus contextos, envolver o usuário e sua família na busca de parcerias para resoluções dos casos. Todos os projetos são organizados em 04 etapas distintas e bem definidas: diagnóstico, definição de metas, divisão de responsabilidades e tarefas e reavaliação. Inicia-se com uma reunião do NASF onde se levanta os usuários envolvidos, a localização e os elementos relevantes do território, queixas, arranjo familiar, situações e demandas, ações clínicas já realizadas, avaliando-se as vulnerabilidades e construindo o diagnóstico da situação. Em seguida são convocados para estudo de caso, outros sujeitos da rede intersetorial, bem como outras pessoas envolvidas com o cuidado do usuário em questão. Nesta reunião, define-se uma pessoa de referência para o caso, a priori que possua vinculo com o usuário e seja capaz de acompanhar o desenvolver do processo. É então feita a pactuaçao dos objetivos e definição das propostas de intervenção. Para isso realiza-se uma divisão de tarefas-responsabilidades entre a equipe e a equipeusuário-família, construindo um cronograma, com metas e datas bem definidas, buscando resoluções com o envolvimento e não fazendo por ele. Conforme as metas vão sendo ou não cumpridas no cronograma, o profissional de referência convoca os envolvidos para reavaliação periódica do caso, redirecionando as ações, concluindo ou encaminhando para outros setores conforme a necessidade. Desde a implantação do NASF no município de Piranga, foram realizados 32 PTS, destes, 18 obtiveram resultados satisfatórios. Alguns entraves como necessidade de avançar no que diz respeito ao trabalho intersetorial, aprimoramento da prática do trabalho em equipe, desenvolvimento nos usuários da noção de auto cuidado e aprimoramento da noção de coresponsabilidade pela saúde em todos os envolvidos foram fatores dificultadores em casos não solucionados. Conclui-se que a gestão pública precisa melhorar a compreensão-tratamento do conceito ampliado de saúde. Porém, o desenvolvimento dos PTS permitiu um novo olhar para o cuidado, a descoberta de uma nova maneira de se trabalhar, casos desacreditados quando cuidados de forma isolada foram resolvidas graças ao PTS.

Descritores: Saúde da Família; Vulnerabilidade. 